\section{Mrs Short's recipe for better prison health}

If the recommendations of Mrs Renee Short's Social Services Committee report on the prison medical service are taken up the health care services in prisons will in the future be much better than they are now. ${ }^{1}$ Too often debates over prison health services have concentrated on what in the end are sterile controversies-whether prisoners are drugged as a method of control and whether the prison medical service should be taken over by the National Health Service. Mrs Short's committee has not ignored these questions but has devoted only limited space to them. Instead, it has produced a highly practical report that will be a useful working document for the prison medical service-and this must be due in good part to the director of the service, Dr John Kilgour, cooperating so closely and willingly with the select committee. This is the select committee system working at its best: a strong light has been shone into a dark corner and revealed not monsters but rather grime and cobwebs that must be swept away.

The committee began its work more than a year ago and has received a great deal of evidence as well visiting many prisons at home and abroad. Anxiety about the adequacy of prison health care services prompted the study, and the report acknowledges the part played by the articles published in the $\mathrm{BMJ} .^{2-4}$ Rather in line with those articles, the committee has recognised that tinkering with the medical services will not be enough. No matter who takes the radiographs and how good the medical records, such small changes will count for little so long as we have prisons that are so overcrowded, unsanitary, degrading, and uncivilised. A report published less than a month ago showed that more than a quarter of prisoners are still locked in their cells each night without access to lavatories and have to "slop out" each morning. ${ }^{5}$ What is more, in England and Wales almost 47000 prisoners are being locked up each night in accommodation intended for less than 41000 . The members of the committee visited prisons in Sweden and the Netherlands and saw for themselves that "appalling conditions are not an inevitable part of a prison system." Their first recommendation is thus that ways must be found to reduce overcrowding and improve conditions, and building new prisons is not the answer. Rather sentencing policy must be changed and much greater use must be made of non-custodial sentences.

After the rumours that it had heard the committee was surprised by the generally good standard of care in prisons for physical ailments. Nevertheless, it has made many recommendations on how the care might be improved. One small one, that radiographs should be taken only by qualified radiographers in approved conditions, is hardly a radical suggestion, and the Home Office will surely act on this even if it does cost money. Much more radical to those steeped in prison culture is the recommendation that doctors should be given discretion to allow prisoners to keep in their cells limited quantities of simple drugs. At the moment prisoners are not allowed so much as an aspirin or a tube of acne ointment. Yet the benefit of their having small amounts of drugs would be not only that the load on prison doctors might be reduced but also that this would be one small, but highly symbolic, step towards making prisons as much like the outside world as possible. Another such step would be to allow prisoners to chose their own doctor. The committee does not go so far, but it does suggest extending to convicted以 prisoners the right that remand prisoners have to seek a second medical opinion at their own expense without theo permission of the prison doctor.

Both the committee and Dr Kilgour identified prison $\widehat{\widehat{C}}$ medical records as seriously deficient. At the moment $a^{5}$ prisoner may have up to three different records, and the committee has recommended that these should be replacedn by just one. A second problem is that because the records are? not centralised it may take a long time to obtain records when prisoners are transferred to another prison or reconvicted, as sadly most of them are. The committee has thus rec $\frac{0}{0}$ ommended centralisation and possible computerisation. It has also recommended that in the interests of confidentiality a prisoner's medical record should be separate from his maing prison record. These changes are all long overdue, as arebetter systems for ensuring interchange of information between the NHS and prisons-though the committee hasw not made such definite recommendations on this.

Another headache of prison doctors is the excessive remanding into custody of offenders for medical assessment : Between January 1984 and March 1985 the doctors at Brixton prison prepared 3184 psychiatric and 23 physicals reports. Many of these could have been written without the offender being remanded into the unremitting squalor of Brixton prison, and the committee would like magistrateso and judges to make much more use of other ways of preparing reports. The Home Office has, however, been advocating this itself for some time, and the committee had no new ideas on how it might be achieved. A newer idea is that all psychiatric reports should ultimately be prepared byo doctors with psychiatric training and qualifications, and newest of all is the recommendation that those psychiatristso might have access to NHS facilities into which they could if necessary take the offender.

This is one way in which the continuing scandal of the mentally ill being held in prison rather than hospital might be $\underset{\overrightarrow{\vec{A}}}{\stackrel{\Omega}{2}}$ resolved. Generally, the committee does not have much new to suggest on this issue, but the firm call to stop the psychiatric prison at Grendon degenerating into "just anothero prison for want of resources" will be welcomed.

Welcome too are many of the other suggestions of the committee-on, for instance, abolishing Crown immunityo for prisons, creating a unified nursing service modelled 3 . perhaps on that in Scotland, and ensuring that full timeo doctors spend a day a week working outside prisons. I was $₹$ disappointed, however, that it did not spell out more응 specifically the importance of research in prisons. It has $N_{\sigma}$ suggested that studies be undertaken on the effects of $\supset$ overcrowding on prisoner's health, on suicidal behaviour, and on other subjects, but it has not recommended that the prison medical service should put time and money aside to encourage research. This may sound like a quibble, buto doctors understand better than politicians how researcho keeps professions and institutions alive-and the prison medical service needs to be kept stimulated after waking $\stackrel{\text { ? }}{+}$ from what might be described as a prolonged slumber.

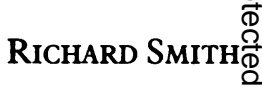

Assistant editor, $B M \mathcal{F}$

1 House of Commons Social Services Committee. Prison medical service. London: HMSO, 1986. 2 Smith R. Prison health care. London: BMA, 1984.

3 Smith R. Ample scope for improving the health of prisoners. Br Med f 1984;288;1939-40.

4 Smith R. Do we need an inquiry into prison health care? Ambov Quarterly 1984;14:1.
5 National Association for the Care and Resettlement of Offenders. Sanitation in prisons. London? NACRO, 1986. 